\title{
Sharing Economy: Why the Turkish consumers use Airbnb?
}

\author{
Volkan Yakin ${ }^{1}$ \\ Abant izzet Baysal University, Bolu, TR \\ Tel: +90 5327949590 E-mail: volkanyakin@yahoo.com \\ Ayşe İdil Kacar \\ Celal Bayar University, Manisa, TR \\ Tel: +90 5443118386 E-mail: idilkacar@yahoo.com \\ Canan Ay \\ Celal Bayar University, Manisa, TR \\ Tel: +905336220551E-mail: ayifakatcanan@yahoo.com
}

Received: 7 May 2017/ Revised: 20 June 2017/ Accepted: 22 June 2017/Published online: 4 August 2017

\begin{abstract}
In recent years, the sharing economy has stimulated the development of entities that have contributed significantly to sustainability through the impact of technological, demographic, and cultural changes observed in society. This research aims to determine the motivation of participation of the Turkish consumers contributing to the sharing economy by using the self-determination theory. For this purpose, a questionnaire was conducted with 160 participants contributing to the sharing economy through the use of Airbnb, which is the most commonly used among sharing economies around the world. Examining the results of the research, it is noted that among the three motivational factors (economic benefit, enjoyment, sustainability) which have a positive effect on attitude, only the level of perceived enjoyment has the highest effect on the attitude and also an effect on the behavior intention.
\end{abstract}

JEL classification: M30, M31, O18, Z30

Keywords: Sharing economy, Consumer behaviors, Airbnb

\section{INTRODUCTION}

The economic power of consumer that increases gradually generates different commercial methods. The recent growing body of consumer communities is one of the fields influenced by the consumer power. Sharing is the underlying matter for such consumer communities. These communities taking enormous advantage of technology and Internet facilities lead to a new

\footnotetext{
Correspondence: Volkan Yakın, Gerede School of Applied Science, Abant Izzet Baysal University, Gerede, Bolu, Turkey. E-mail: volkanyakin@ yahoo.com
} 
commercial structure. The structure is called sharing economy and grabs attention due to the rapid growth rate and its diversities.

Sharing economy has begun to provide a solution to such areas as accommodation, transportation, education, and food needs. Consumers gain economic benefits by sharing assets in hand (house, automobile, second-hand clothing, time, books etc.) with the people who are in need of them. Sharing economy differs from other social commercial methods in terms of creating collective benefit. Monetary payment can be provided in exchange for the benefit or intangible elements can be accepted as well. Sharing economy draws strength from its spreading rate and the number of users. Nowadays, it is possible to speak of the communities that are active on the international scale.

Why and how people are getting motivated to participate in sharing economy is considered to be the most engrossing issue. This research aims to obtain information about factors which motivate sharing consumers in Turkey. In line with this purpose, the participants' attitudes towards Airbnb known for having the largest number of users are measured with the self-determination theory, and the results have been interpreted accordingly.

\section{SHARING ECONOMY}

\subsection{Sharing Economy}

Through the improvement of Web 2.0 software and increasing web accessibility, possibilities for people to share products and services via the social network have also improved considerably. Especially, in the early nineties, people showed interest in $\mathrm{P}_{2} \mathrm{P}^{1}$ sharing upon the release of Napster program which allows sharing of music files (mp3). In that period, the tendency of societies to possess goods and services began to change in the direction of sharing (thecirculars. org). Today, an enormous number of online media help to share tools, clothes, or entertainment products in digital environments (Balck \& Cracau, 2015).

The act of sharing is associated with different names in different studies carried out thus far. While Botsman and Rogers (2010) prefer using the term "collaborative consumption" in their book regarding sharing economy called 'What is mine is yours,' Belk (2010) uses the term 'sharing'. Gansky (2010) uses the term 'the mesh' whereas Lamberton and Rose (2012) favors the terms 'commercial sharing systems.' Moreover, the terms 'co-production', 'co-creation', 'prosumption', 'product-service systems' etc. are also used (Belk, 2014). Among the abovementioned terms, 'co-consumption' has the most frequent occurrence on account of the tremendous impact of the book by Botsman and Rogers (2010). Besides, Belk (2014) emphasizes that the gratuitous "sharing activities" are different from the "collaborative consumption," and therefore, it is not considered as "sharing activity" but "collaborative consumption" when the sharing is for a fee or other benefits (Belk, 2014). What Zervars and Byers (2013) define as the sharing economy is all the multi-functional technologies that enable passive investments to be brought into the common use of people in return for a fee. On the other hand, Hamari et al. (2015) define the sharing economy as an umbrella term surrounded by information and other computer technologies that support product and service sharing in online environments.

While there are variations in the definition and conceptualization of the formations of sharing economies, there are two fundamental characteristics of these formations catching attention in general: (1) It allows products and services to be used temporarily without purchasing them completely. (2) The product and service providers and users communicate through advanced web and mobile data networks. Another common feature that can be regarded is that the information about the related formations spreads around through oral marketing by means of social networks (Belk, 2014; Gansky, 2010). Based on these common features, sharing economy organizations/ 
structures can be defined as all types of online environments where the people who share their products and services via Web 2.0 tools and mobile data networks with or without an expectation of a return meet with the people who can make use of / benefit from these products and services without actually purchasing them. However, since our work focuses on the activities related to these formations rather than the formations of the direct sharing economy, the activities of these formations of sharing economy are generally referred to as "sharing consumption" in the following section. There are a number of factors that affect the development of collaborative consumption. Especially with the economic stagnation in 2008, it has been observed that people become more willing to share the possessions that they think are important and can be valorized.

The increase in production and selling costs due to the climate change and other environmental problems (especially non-deposit products) is among the other main driving forces. The individualization of digital technologies enabling users to reach other users quickly and efficiently, free service applications, online payment systems, low commission fees, overcoming the trust issue via social networks etc. are among the other facilitating factors that prepare the ground for the rapid development of collaborative consumption (Cohen and Kohetzman, 2014; Gansky, 2010; Sundararajan, 2014; http://www.hbrturkiye.com).

Nowadays, it is seen that collaborative consumption is realized in all sectors and almost the entire world. The formations of sharing economy such as "Airbnb," Zipcar, "Uber" that are active globally are the successful examples (thecirculars.org, 2013). Sundararajan (2014) evaluates the formation of sharing economy under four categories:

1. Lending or renting of owned goods with a different purpose than the earlier one: This category creates a new business opportunity for individuals who are not professional goods/service providers in markets where online environments are created. Airbnb is an example of the formations in this category allowing people to become entrepreneurs. The companies offering their meeting rooms to start-ups for free or with low rates when not in use and "couchsurfing" providing a house with free of charge can be considered as similar examples of place-service formations. "Zipcar," which operates without a branch and offers short-term car rental, and "blablacar," which connects drivers and co-travellers for a ride-sharing with a low rate, also fall into this category.

2. Professional service providers: The formations in this category create a new service channel for existing service providers offering different services and often expand business opportunities by ensuring that people are in pursuit of becoming entrepreneurs rather than the employees of traditional organizations. For example, Uber has given the opportunity to provide a city-to-city service from one point to another. The formations such as "TimeBank," which is created under the name of "zumbara" in our country, allow users to trade their expertise with each other based on the time of contribution instead of money, which is among the entities in this category.

3. General-purpose self-employed recruitment: These formations provide new markets for the self-employed in various fields. For example, Tubitekuz, a self-employed informatics specialist, and ProSranslate, designed for translation specialists to find jobs, are among the local formations that can be found all around the world. The firm "Quirky," which allows entrepreneurs who want to follow up their ideas and designs to create a branded product also falls into this category.

4. Goods sales of peer to peer: Formations in this category allow entrepreneurs to sell goods directly to consumers like the way "eBay" works.

The factors that influence the development of the sharing economy also include a number of intrinsic and extrinsic motivations that cause individuals to participate in collaborative consumption. It is seen that recent researches that attempt to determine the motivations of participants contributing to the development of sharing economy focus on the intrinsic factors 
such as having a sustainability approach (less consumption, consumption in proportion to need, etc.) and enjoying being a participant, feeling good, appreciating to try new things as well as more visible motivation factors such as epistemic (having knowledge, expanding horizons) and obtaining economic and social benefits (Hamari et al., 2014; Kim et al., 2015; Stors and Kagermeir, 2015).

\subsection{Rising Power in Sharing Economy: Airbnb}

While there has been a significant increase in the participative consumption activities in recent years, Airbnb stands a step forward in the formation of these activities in terms of expansion and pace of development. Firstly, Airbnb was implemented in 2007 by two friends named Joe Gebbia and Brian Chesky living in San Francisco when they rented one of their rooms during a congress event where all the hotels in the city were booked by setting up a website named "airbedandbreakfast.com" In the following year when Nathan Blecharczyk, a computer programmer, joined them as an entrepreneurial partner, the initiative gained significant momentum and has continued to evolve ever since (http://www.telegraph.co.uk).

Airbnb, which is on the list of innovative brands today, has reached an economic value of approximately 10 billion dollars according to an announcement last year (www.netvaluator.com) (www.fastcompany.com). Renting rooms over airbnb.com, which allows house owner users to rent out a room or the whole place to strangers, intrigues 10 million people a year over hotels. In the past year, Airbnb operating in 192 countries has doubled the number of house owner users and reached 550 thousand users (Today, the number is around 700 thousand) (www.wired.com).

Airbnb.com has had 50 million members as host users and guest users in a short period of time since it was built (http://expandedramblings.com).

\section{THE SHARING CONSUMER BEHAVIOR AND SELF-DETERMINATION THEORY}

While planning the methodology of the research, it is aimed to better understand and evaluate the motivational elements underlying the participation behavior of people in collaborative consumption websites. Sharing consumer behavior is defined by behavioral intent. The attitude towards collaborative consumption as a prelude to this intention has been addressed. The Self-Determination Theory has been used to determine the factors that influence the attitude and mentioned behavior. When deciding on this, various theories of behavior, which are mentioned in the literature about social commerce and sharing economy, have been examined. Many researches show that while self-determination behavior level is increased, the effect of the mentioned behavior is increased; also it is more consistent and complies with the social networks in a better way (White, 2015).

The Self-Determination Theory is a general theory of motivation and focuses on what factors can motivate new behavior and how it can be sustained (Ryan et al., 2008). The theory, which was put forward by Edward Dai in the 1970s, seeks to establish the conditions for self-motivation (Ryan and Deci, 2000). Many studies show that motivation based on self-determination is a good predictor of specific behavior (Deci and Ryan, 2000; Haggervd 2009; Ryan, Rigby and Przybylski, 2006; Transcript: Webb et al., 2013). It is considered that self-motivation can be handled as a preliminary indicator of participation behavior in the sharing economy and of attitude regarding behavior.

Behavioral intention is used to estimate the motivational factors that affect a behavior. In general, in order to estimate the behavioral intention, the attitude regarding behavior is tried to be determined (Ajzen, 1991). For this reason, attitude and behavioral intention relationship is established in our model. Also, motivation elements are handled within the quadruple 
classification. It is stated that participation in social commerce and sharing communities needs intrinsic and extrinsic motivations. The Self-Determination Theory suggests that people must have certain predispositions to be compatible with new experiences (Enström and Elg, 2015). The motivations that cause behavior are also divided into extrinsic and intrinsic motivations. Hamahari et al. (2015) made a quadruple classification in terms of sharing consumption indicating that the economic benefits, enjoyment, reputation, and sustainability motives would cause sharing behavior. In this case, the desire to gain reputation and economic benefit provide extrinsic motivation while sustainability and enjoyment provide intrinsic motivation. Our research is also based on this model.

Many of the motivation research has shown that both intrinsic and extrinsic motivational factors are important (Zhao and Zhu, 2014). The behaviors, which aim at seeking a prize or avoiding punishment, are defined as extrinsic. The behavior of a person who starts doing physical exercise upon the recommendation of a doctor is an example of extrinsic motivation (White, 2015). In this case, one's behavior is based on the charm of the prize or the sanction of the prisoner. İntrinsic motivation occurs when people enjoy performing a behavior or are interested in an action (Deci and Ryan, 1985).

Within the context of consumer behavior, it is stated that the behavioral intention can be determined by first looking at whether the product or service is utilitarian or hedonic (Van der Heijden, 2004). In the collaborative consumption communities, the hedonic feature is the predominating one. But it is known that encouraging people's participation, utilitarian incentives should be utilized as much as hedonic features. Bock et al. (2005) argue that extrinsic incentives such as cash prizes are used to encourage information sharing, and participation behavior becomes more enthusiastic as the extrinsic reward expectation increases in social trade. For this reason, the economic benefit of collaborative consumption is considered as an extrinsic motivation factor.

The desire to gain reputation is one of the benefits that encourage social trade participation. Especially the participants who provide information believe that they will benefit by sharing their experiences with others because they hope that they will receive help from others in the future. As a result, it gives them respect and a more positive image (Kankanhalli, 2005).

It is known that socialization-based activities are generally entertaining and enjoyable (Gatautis and Medziausiene, 2013). All of the online purchasing activities are hedonic activities, so these must be experiences that people enjoy leading to intrinsic motivation (Shen, 2012). It is considered that the people involved in the social sharing experience should also enjoy this experience at some point. The sustainability factor Hamahari et al. (2015) add is a fact based on the feature of creating social benefits in regard to collaborative consumption.

\section{PURPOSE AND SIGNIFICANCE OF THE STUDY}

While the literature about the sharing economy is expected to become more and more prosperous, it seems that it has not yet achieved the necessary momentum. While there are some studies conducted in developed countries such as the USA, the UK etc., this study is conducted in a developing country. The focus of this research is, in particular, the fact that our country and any other developing Middle East country lack the studies that focus on determining the underlying reasons for participation in the sharing economy. This is important because sharing economy platforms are as mentioned above new emerging markets which provide many advantages for people, and if the factors motivating the participation behavior of sharing consumer are known, the studies which ensure continuity and increase market share can be conducted. On the other hand, if we look at it in terms of competing for traditional entities, necessary precautions can be taken to adapt to this change. There have been few studies conducted in the world that support the sharing economy and that target only 'active users' so far. This is the starting point of this study, 
and the research is conducted with only Turkish participants to determine the local motivations. Due to a large number of communities operating in the area of the sharing economy, it is thought that there should be a restriction. When compared to other sectors, it is clear that the sharing economy has improved further in the accommodation market. This development also brings new questions to minds about the consumer motivations for accommodation preference. In view of the fact that most of the previous studies on the sharing economics are related to Airbnb and allow comparison of the results, it is decided that Airbnb, which is the most internationally recognized among the sharing economies, will provide a suitable environment.

\section{LIMITATIONS OF THE STUDY}

The study is carried out with a limited sample due to the time and cost restrictions. Not having had enough awareness about the issue in Turkey yet caused difficulties in reaching the concerned person. The fact that the amount of experience with people is not the same is also a limitation. The results obtained from all these causes are considered to provide important contributions on the issue, and yet this cannot be generalized to all Turkey.

\section{RESEARCH METHOD AND HYPOTHESES}

The study employs the initial model and scale used in a study by Hamahari et al. (2015). The necessary adaptations on the scale of the model were made subsequent to the pilot study and confirmatory factor analysis. The questionnaire is used as a research tool. It is spread over the Internet for a period of 4 months. Different social media environments and electronic mail are used to reach the users. A total of 160 questionnaires is gathered for the analysis. The findings are analyzed with Structural Equation Modeling, and the results are interpreted.

Hypotheses tested according to the research model are as follows:

$\mathrm{H}_{1 \mathrm{a}}$ : the perceived sustainability positively affects the attitude regarding sharing consumption.

$\mathrm{H}_{1 \mathrm{~b}}$ : the perceived sustainability positively affects the intention of behavior regarding sharing consumption.

$\mathrm{H}_{2 \mathrm{a}}$ : the perceived enjoyment level positively affects the attitude regarding sharing consumption.

$\mathrm{H}_{2 \mathrm{~b}}$ : the perceived enjoyment level positively affects the intention of behavior regarding sharing consumption.

$\mathrm{H}_{3 \mathrm{a}}$ : the perceived gaining reputation positively affects the attitude regarding sharing consumption.

$\mathrm{H}_{3 \mathrm{~b}}$ : the perceived gaining reputation positively affects the intention of behavior regarding sharing consumption.

$\mathrm{H}_{4 \mathrm{a}}$ : the perceived economic benefit positively affects the attitude regarding sharing consumption.

$\mathrm{H}_{4 \mathrm{~b}}$ : the perceived economic benefit positively affects the intention of behavior regarding sharing consumption.

$\mathrm{H}_{5}$ : the attitude regarding collaborative consumption positively affects the intention of behavior. 


\section{RESULTS AND DISCUSSION}

When the pilot study is carried out, the Cronbach Alpha scale is calculated to be 0.950 . It has been decided that the scale is eligible for the research. The reliability of the scale is high according to the analysis $(\alpha=0.911,0.80 \leq \alpha<1.00)$. The Confirmatory Factor Analysis is performed first by using the Amos 22 program, and then using Structural Equation Modeling, hypotheses have been tested in order to verify scale factors in the study. As a result of Confirmatory Factor Analysis, the variable of "Collaborative consumption allows me to save time" under the dimension of providing economic benefit is removed from analysis due to the inability to measure the attitudes and behavioral intentions.

When the values of appropriateness obtained from the confirmatory factor analysis are examined; the value of $\chi 2$ / df is determined to be 2,198 . This value is acceptable when it is below 5 (Wheaton et al., 1977, p. 99). In addition, among the other compatibility value, GFI value is 0,976 , CFI value 0,931 , NFI value 0,914 , and RMSEA value is 0,08 , which is an expected range and indication of good compatibility.

The results of the demographic analysis are presented in Table 1. According to the gender distribution of the sample, $45.62 \%$ is female, and $54.38 \%$ is male. When the educational status of the participants is concerned, it is observed that they have high school (1.87\%), bachelor $(56.87 \%)$, and postgraduate (41.25\%) degrees. When we look at the income level, it is determined that most of the participants $(51,87 \%)$ have a monthly income of $4000 \mathrm{TL}$ and above. $21,25 \%$ of the participants have 3001-4000 TL income while 13,12\% have 2001-3000 TL and 6,87\% 1001-2000 TL and below $1000 \mathrm{TL}$. According to the age distribution, 0,06\% of the people are under 20 years old, $30 \%$ between the ages of $26-30,31,9 \%$ between the ages of $31-35,13,8 \%$ between the ages of $36-40$, and $10 \%$ are over 40 years old. $31,25 \%$ of the participants are married, and $68,75 \%$ are single.

Table 1

Demographic Analysis Results

\begin{tabular}{|c|c|c|c|c|c|c|c|c|c|c|c|}
\hline & & $\mathbf{N}$ & $\%$ & & & $\mathbf{N}$ & $\%$ & & & $\mathbf{N}$ & $\%$ \\
\hline \multirow[t]{2}{*}{ Gender } & Female & 73 & 45,62 & $\begin{array}{l}\text { Educational } \\
\text { status }\end{array}$ & Literate & 0 & 0 & $\begin{array}{l}\text { Marital } \\
\text { Status }\end{array}$ & Married & 50 & 31,25 \\
\hline & Male & 87 & 54,38 & & $\begin{array}{l}\text { Primary } \\
\text { educ. }\end{array}$ & 0 & 0 & & Single & 110 & 68,75 \\
\hline \multirow[t]{6}{*}{ Age } & $<20$ & 1 & 0,06 & & $\begin{array}{l}\text { High } \\
\text { School }\end{array}$ & 3 & 1,87 & Income & $\begin{array}{l}1000 \\
\text { and below }\end{array}$ & 11 & 6,87 \\
\hline & $20-25$ & 22 & 13,8 & & University & 91 & 56,87 & & $1001-2000$ & 11 & 6,87 \\
\hline & $26-30$ & 48 & 30,0 & & $\begin{array}{l}\text { Master / } \\
\mathrm{PhD}\end{array}$ & 66 & 41,25 & & $2001-3000$ & 21 & 13,12 \\
\hline & $31-35$ & 51 & 31,9 & & & & & & $3001-4000$ & 34 & 21,25 \\
\hline & $36-40$ & 22 & 13,8 & & & & & & $\begin{array}{l}4000 \\
\text { and above }\end{array}$ & 83 & 51,87 \\
\hline & $>40$ & 16 & 10,0 & & & & & & & & \\
\hline
\end{tabular}


It is seen that while $52.17 \%$ of the participants had experience in other forms of sharing economies than Airbnb (mainly couchsurfing, uber, and blabla), $47.82 \%$ of them do not have any other sharing consumer experience. It is seen that $77.91 \%$ of the participants have experienced collaborative consumption more than once through Airbnb. It was found out that only $13,49 \%$ of the people who rented houses benefited from Airbnb in domestic. While $90.6 \%$ of participants indicated that collaborative consumption experiences had a positive change in their holiday/travel perceptions, and $97.51 \%$ of all participants indicated that they would continue to rent the house from formations such as Airbnb etc. It is seen that $78.88 \%$ of participants do not support the idea that the businesses with commercial identity such as hotels etc. make a profit over formations like Airbnb since they found it against the spirit of sharing economy. $72.43 \%$ of participants stated that they preferred Airbnb for spiritual benefits based on experience (to contact with local people, get tips from the host about traveling, and get different experiences etc.) whereas $26,07 \%$ stated that they preferred it for the economic benefits (to earn money, save money, and compare prices), and $1,44 \%$ preferred it for other reasons.

The values for the hypothesis test are shown in Table 2. All of the intrinsic and extrinsic motivational factors (perceived sustainability, perceived enjoyment, perceived reputation, and perceived economic benefit) are found to be effective in sharing consumption. It is seen that while perceived sustainability has a positive effect on perceived enjoyment level and perceived economic benefit attitude, the desire to obtain perceived reputation negatively interacts with attitude.

Table 2

Hypothesis Test Results

\begin{tabular}{|c|c|c|c|c|c|}
\hline Hypotheses & Way & P Value & Coefficient & $\mathrm{t}$-Value & Result \\
\hline $\begin{array}{l}\mathrm{H}_{1 \mathrm{~A}} \\
\mathrm{H}_{1 \mathrm{~B}}\end{array}$ & $\begin{array}{l}\text { Sustainability } \rightarrow \text { Attitude } \\
\text { Sustainability } \rightarrow \text { Behavioral intent }\end{array}$ & $\begin{array}{l}0.001 \\
0.526\end{array}$ & $\begin{array}{r}0.148 \\
-0.037\end{array}$ & $\begin{array}{r}3.248 \\
-0.635\end{array}$ & $\begin{array}{l}\text { Accepted } \\
\text { Rejected }\end{array}$ \\
\hline $\begin{array}{l}\mathrm{H}_{2 \mathrm{~A}} \\
\mathrm{H}_{2 \mathrm{~B}}\end{array}$ & $\begin{array}{l}\text { Enjoyment } \rightarrow \text { Attitude } \\
\text { Enjoyment } \rightarrow \text { Behavioral intent }\end{array}$ & $\begin{array}{l}0.001 \\
0.008\end{array}$ & $\begin{array}{l}0.791 \\
0.386\end{array}$ & $\begin{array}{r}12.851 \\
2.669\end{array}$ & $\begin{array}{l}\text { Accepted } \\
\text { Accepted }\end{array}$ \\
\hline $\begin{array}{l}\mathrm{H}_{3 \mathrm{~A}} \\
\mathrm{H}_{3 \mathrm{~B}}\end{array}$ & $\begin{array}{l}\text { Gain reputation } \rightarrow \text { Attitude } \\
\text { Gain reputation } \rightarrow \text { Behavioral intent }\end{array}$ & $\begin{array}{l}0.001 \\
0.071\end{array}$ & $\begin{array}{l}0.183 \\
0.113\end{array}$ & $\begin{array}{r}-3.927 \\
1.803\end{array}$ & $\begin{array}{l}\text { Accepted } \\
\text { Rejected }\end{array}$ \\
\hline $\begin{array}{l}\mathrm{H}_{4 \mathrm{~A}} \\
\mathrm{H}_{4 \mathrm{~B}}\end{array}$ & $\begin{array}{l}\text { Economic benefit } \rightarrow \text { Attitude } \\
\text { Economic benefit } \rightarrow \text { Behavioral intent }\end{array}$ & $\begin{array}{l}0.001 \\
0.884\end{array}$ & $\begin{array}{r}0.371 \\
-0.012\end{array}$ & $\begin{array}{r}6.739 \\
-0.146\end{array}$ & $\begin{array}{l}\text { Accepted } \\
\text { Rejected }\end{array}$ \\
\hline $\mathrm{H}_{5}$ & Attitude $\rightarrow$ Behavioral intent & 0.003 & 0.488 & 2.936 & Accepted \\
\hline
\end{tabular}

When we look at the conclusions regarding the behavioral intentions related to the sharing consumption, different results are obtained. Although the attitude towards the collaborative consumption is found to have a positive effect on the behavioral intention, the influence of the motivational elements on the behavioral intention is limited. The effect of perceived enjoyment level on behavioral intentions related to collaborative consumption is positive. The perceived sustainability, the perceived desire to gain reputation, and the hypotheses about the effect of perceived economic utility are rejected.

Figure 1 shows the variance values for the Result Model and all variables. The R2 value for attitude is obtained as 0.82 , The $\mathrm{R} 2$ value of intention of behavior takes places according to attitude is calculated as 0.67 . 
Figure 1

Result Model

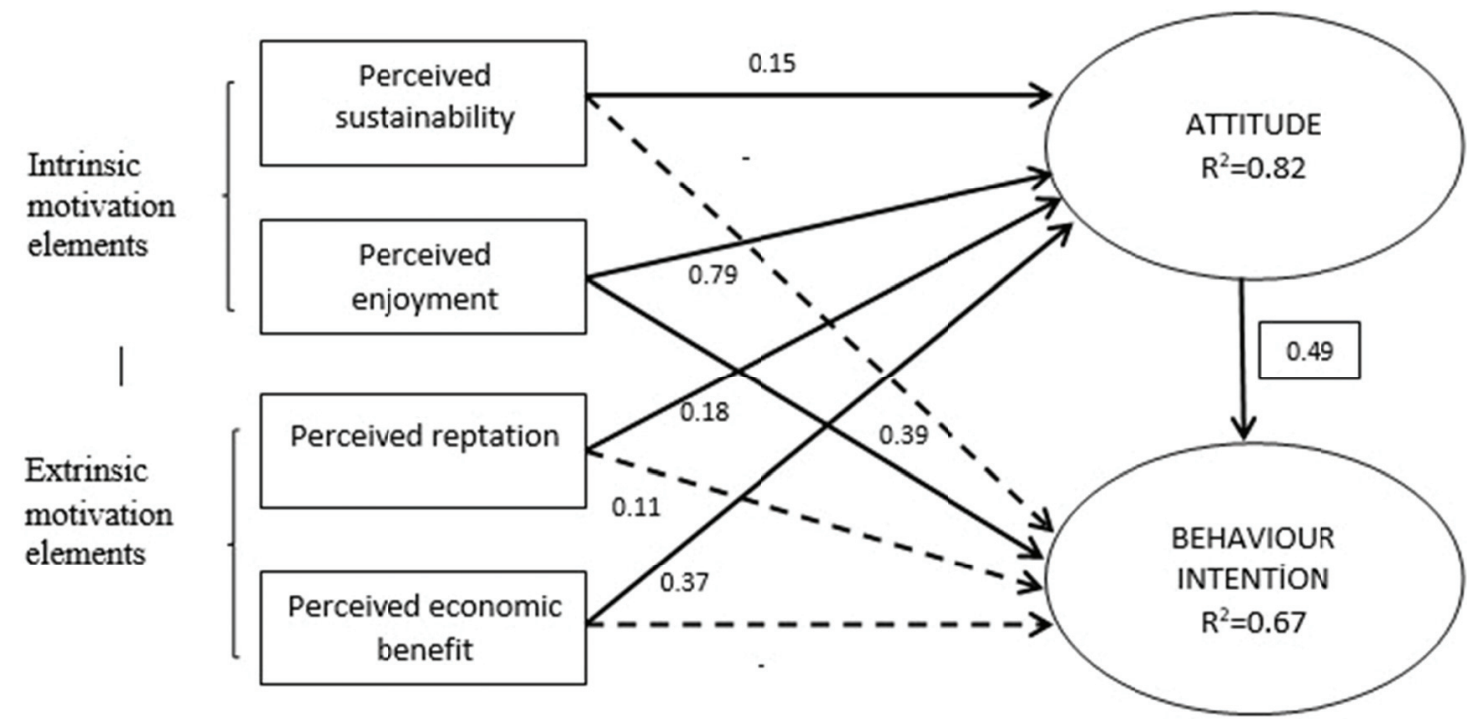

Source: own study.

As a result of the analysis, it is seen that the perceived joy level has the greatest influence on attitude. It is known that intrinsic motivational elements present tendencies to assimilate a particular attitude or behavior, and enjoyment is also one of the basic elements (Csikszentmihalyi and Rathunde, 1993). The Self-Determination Theory has already emphasized the importance of inherent motivations of attitudes and behaviors in essence. Also, it is stated that the intrinsic psychological needs of people such as the desire to enjoy have a positive impact on selfmotivation. (Ryan and Deci, 2000). From this point of view, the level of enjoyment that influences the motivation to participate in the sharing economy is a consistent outcome.

It is seen that the perceived level of sustainability has a positive effect on attitude, but it remains at the lowest level among the determined factors. This result differs from a similar study carried out by Hamaharivd (2015).

Extrinsic motivational elements are the elements to which one usually applies to get a prize or avoid a penalty. However, it should not be forgotten that intrinsic motivations should be compatible with extrinsic motivations (Gagne and Deci, 2005). According to the model, it is seen that perceived economic benefit has a more powerful influence compared with the desire to gain reputation on attitude. In the sharing economy, consumers are basically meeting their needs by "sharing" with other consumers rather than buying many products and services that they need (Özata et al., 2015). Economic benefit emerges as an effective extrinsic motivation factor due to the products and services that are available at lower costs and are also a source of income for those who share products and services at the same time. Bockvd (2005) argues that while the extrinsic reward expectation increases in social trade, participation behavior becomes more voluntary.

According to the Self-Determination Theory, the people are active organisms with an innate tendency to improve; however, this tendency does not spontaneously take place. It emerges with the support of the social environment (Ersoy-Kart and Güldü, 2008). In social communities, the desire to gain reputation among the concepts related to social influence is a factor of which positive impact is expected related to the participation in the sharing economy (Kankanhalli, 2005). When the results of the research are examined, it is determined that there is a positive effect. 


\section{CONCLUSION AND RECOMMENDATIONS}

The concepts such as sharing economy and collaborative consumption have become current issues and begun to be discussed frequently due to technological developments that are shaping consumer behavior. People have opened their houses, cars, even their talents, and time to sharing and/or exchanging due to online environments that mediate the sharing economy. These new emerging markets are also opening new ways to trading activities and become game changers. Especially the successes of the marketers both in these new markets or traditional ones are much related to consumer's reactions to the new developments. In the light of these developments, this study aims to determine the general profiles of Turkish consumers who are engaged in the sharing of consumption activities on Airbnb, the reasons for the use of Airbnb, and the motivations that enable them to be part of collaborative consumption activities.

As a result, it is seen that those who perform collaborative consumption are highly educated, their income level is above the Turkey average and they are mainly single women and men aged 26-35 years. In addition, it is also understood in the majority of sharing consumers that there is consciousness about the sharing economy and they intend to continue the positive experiences they have achieved as a result of collaborative consumption.

Another important result of the research includes identified motivational factors. It is expected that the motivational elements that have positive effects on the attitudes will reflect the general behavior intention. When we look at the results for motivation, it is seen that among the three motivational factors (economic benefit, enjoyment, sustainability) which have a positive effect on attitude, only the level of perceived enjoyment has the highest effect on the attitude and also an effect on the behavior intention. It is understood that the other two motivational factors, especially the economic benefit with a higher attitude score, are important for the participants, but the main factor which motivates the person in the real sense is the enjoyment motivation. This situation shows consistency with the answers of participations regarding using Airbnb. One of the reasons can be that the participants of the study are the people who rent house/room rather than the people who rent out their house/room. However, the level of income of sharing consumers in the study is above average (although they are aware of the economic benefits of collaborative consumption), it may mean that the experiences they will gain are more important to them.

On the other hand, it has been observed in the studies carried out in culturally diverse Western countries that sustainability motivation affects behavior. Although there is a low level of positive effect on attitudes as a result of our research, nonaffected behavior can be explained by the fact that in our country sustainability is not settled enough to transform the consciousness into behavior. The reasons for the difference can be the subject of further research of whether Turkish consumers do not evaluate the sharing economy from an environmental point of view.

Moreover, it seems logical that the desire to become a recognized person in the sharing communities (desire to acquire reputation) makes sense, but it is understood that it is not a motivator as to motivate the sharing consumers who participate in the research. It can be examined by a more specific and comprehensive research whether the importance of interpersonal relations in the social communities supports the desire to be at the forefront of these relations or not.

Apart from our research, the impact of the sharing economy on the tourism sector, especially on hospitality marketplace, can be further researched. Sharing economies may require different promotional activities when they are evaluated in two different categories (for profit or nonprofit) for the purpose of practitioners. Therefore, alternative ways of marketing communication helping to promote sharing economies can be investigated in a different study. 


\section{References}

67 Amazing Airbnb Statistics and Facts 2016 Available at http://expandedramblings.com/index.php/airbnb-statistics/ [accessed on 2.03.2016].

Airbnb and Hotels: What to Do About the Sharing Economy? 2014 Available at http://www.wired.com/ insights/2014/11/hotels-sharing-economy/ [accessed on 20.04.2016].

airbnb.com is worth $\$ 20,206,350.72$ 2016. Available at http://www.netvaluator.com/www/airbnb.com [accessed on 20.03.2016].

Airbnb: The story behind the \$1.3bn room-letting website 2012 Available at http://www.telegraph.co.uk/technology/ news/9525267/Airbnb-The-story-behind-the-1.3bn-room-letting-website.html [accessed on 10.03.2016].

Ajzen, I. (1991) 'The Theory of Planned Behavior', Organizational Behavior and Human Decision Processes, Vol. 50, pp. 179-211.

Belk R. (2014) 'You are what you can access: Sharing and collaborative consumption online', Journal of BusinessResearch, Vol. 67 No. 8, pp. 1595-1600.

Belk R., (2010) 'Sharing', The Journal of Consumer Research, Vol. 36 No. 5, pp. 715-734.

Bock, G.W., Zmud, R.W., Kim, Y.G., Lee, J.N. (2005) 'Behavioral Intention Formation in Knowledge Sharing: Examining The Roles of Extrinsic Motivators, Social-Psychological Forces, and Organizational Climate', MIS Quarterly, Vol. 29 No. 1, pp. 87-111.

Cohen, B., Kietzmann, J. (2014) 'Ride On! Mobility Business Models for the Sharing Economy', Organization \& Environment, Vol. 27 No. 3, pp. 279-296.

Csikszentmihalyi, M. and Rathunde, K. (1993) 'The measurement of flow in everyday life: Toward a theory of emergent motivation', In Developmental perspectives on motivation, J.E. Jacobs (Ed.), Lincoln: University of Nebraska Press, pp. 57-97.

Deci, E.L., Ryan, R.M. (2000) "The "What" and "Why" Of Goal Pursuits: Human Needs And The Self-Determination Of Behaviour', Psychological Inquiry, Vol. 11 No. 4, pp. 227-268.

Deci, E.L., Ryan, R.M. (1985) 'Cognitive Evaluation Theory, Intrinsic Motivation and Self-Determination in Human Behavior', Perspectives in Social Psychology, Springer, New York, NY.

Engström, J. (2015) 'A Self-Determination Theory Perspective On Customer Participation in Service Development', Journal of Services Marketing, Vol. No. 6/7, pp. 511-521.

Ersoy Kart M., Güldü, Ö. (2008) 'Self-Determination Scale: The Adaptation Study', Journal of Faculty of Educational Sciences, Ankara University, Vol. 41 No. 2, pp. 187-207.

Gagne, M., Deci, E.L. (2005) 'Self Determination Theory and Work Motivation', Journal of Organizational Behaviour, Vol 26, pp. 331-362.

Gansky, L. (2010) The mesh: Why the future of business is sharing, Portfolio/Penguin, New York.

Gatautis, R. and Procedia, A.M. (2014) 'Factors Affecting Social Commerce Acceptance in Lithuania', Social and Behavioral Sciences, Vol. 110, 1235-1242.

Hagger, M.S.,Chatzisarantis, N.L.D., Hein, V., Soos, I., Karsai, I., Lintunen, T. and Leemans S. (2009) 'Teacher, Peer and ParentAutonomy Support in Physical Education and Leisure-Time Physical Activity: A Trans-Contextual Model of Motivation in Four Nations', Psychology and Health, Vol. 24 No. 6, pp. 689-711.

Hamahari, J., Sjöklint, M. and Ukkonen, A. (2015) 'The Sharing Economy: Why People Participate in Collaborative Consumption', Journal of TheAssociation For Information Science and Technology, Vol. 67 No. 9, pp. 2047-2059.

Kankanhalli, A., Tan, B.C.Y. and Wei, K.K. (2005) 'Contributing Knowledge to Electronic Knowledge Repositories: An Empirical Investigation', MIS Quarterly, Vol. 29 No. 1, pp. 113-143.

Özata, F.Z., Er, İ., Öztürk, S.A. and Ağlargöz, F. (2015) 'Ortak Tüketememek: Paylaşma Davranışını Engelleyen Faktörlerin Belirlenmesi Üzerine Bir Araştırma’, 20. Ulusal Pazarlama Kongresi Özet Bildiri, Eskişehir.

Paylaşım Ekonomisi: Benim olan senindir 2013 Available at http://www.hbrturkiye.com/blog/paylasim-ekonomisi/ paylasim-ekonomisi-benim-olan-senindir [accessed on 26.02.2016].

Ryan, R.M., Patrick, H., Deci, E.L. and Williams, G.C. (2008) 'Facilitating Health Behaviour Change And Is Maintenance: InterventionsBased On Self-Determination Theory', The European Health Psychologist, Vol. 10, pp. 2-5.

Ryan, R.M.and Deci, E.L. (2000) 'Self-Determination Theory and the Facilitation of Intrinsic Motivation, Social Development, and Well-Being', American Psychologist Copyright by the American Psychological Association, Inc., Vol. 55 No.1, pp. 68-78.

Ryan, R.M., Rigby, C.S. and Przybylski, A.K. (2006) 'The Motivational Pull Of Video Games: A Self-Determination Theory Approach', Motivation and Emotion, Vol. 30 No. 4, pp. 347-364.

Shen, J. (2012) 'Social Comparison, Social Presence, and Enjoyment in The Acceptance of Social Shopping Websites', Journal of Electronic Commerce Research, Vol. 13 No. 3, pp. 198-212. 
Stors, N., and Kagermeier, A. (2015) 'Motives for Using Airbnb in Metropolitan Tourism—Why do People Sleep in the Bed of a Stranger?' Regions Magazine, Vol. 299 No. 1, pp. 17-19.

Sundararajan, A. (2014) 'Peer-to-peer businesses and the sharing (collaborative) economy: Overview, economic effects, and regulatory issues', Written testimony for the hearing titled The Power of Connection: Peer to Peer Businesses.

The world's most innovative companies 2016 Available at http://www.fastcompany.com/most-innovativecompanies/2014/airbnb [accessed on 20.04.2016].

Van der Heijden, H. (2004) 'User Acceptance of Hedonic Information Systems', MIS Quarterly, Vol. 28 No. 4, pp. 695-704.

Webb, D., Soutar, G. N., Mazzarol, T. and Saldaris, P. (2013) 'Self-Determination Theory and Consumer Behavioural Change: Evidence From A Household Energy-Saving Behaviour Study', Journal of Environmental Psychology, Vol. 35, pp. 59-66.

White, C. (2015) 'The Impact of Motivation on Customer Satisfaction Formation: A Self-Determination Perspective', European Journal of Marketing, Vol. 49 No. 11/12, pp. 1923-1940.

Zhao, Y.C. and Zhu, Q. (2014) 'Effects of Extrinsic And İntrinsic Motivation on Participation in Crowdsourcing Contest: A Perspective of Self-Determination Theory', Online Information Review, Vol. 38 No. 7 , pp. 896-917. 